\title{
Gene alterations in tumor-associated endothelial cells from endometrial cancer
}

\author{
XUE-LIAN DU ${ }^{1,2}$, TAO JIANG ${ }^{2}$, WEN-BO ZHAO ${ }^{1}$, FEI WANG ${ }^{1}$, \\ GUI-LI WANG ${ }^{1}$, MIN CUI ${ }^{1}$ and ZE-QING WEN ${ }^{1}$ \\ ${ }^{1}$ Department of Obstetrics and Gynecology, Provincial Hospital affiliated to Shandong University, Jinan 250021; \\ ${ }^{2}$ Department of Gynecological Oncology, Shandong Tumor Hospital, Jinan 250117, P.R. China
}

Received June 13, 2008; Accepted August 11, 2008

DOI: 10.3892/ijmm_00000064

\begin{abstract}
The alterations in the gene expression profile of tumor-associated human endometrial endothelial cells (HEECs) may allow opportunities for developing new therapeutic approaches to inhibit angiogenesis in endometrial cancer. The aim of this study was to identify the different gene expression pattern between tumor-associated HEECs and normal HEECs. To elucidate the molecular mechanisms governing the abnormal vasculature in endometrial cancer, we examined global expression patterns of purified endothelial cells from three endometrial cancers and three age-matched normal endometria using oligonucleotide microarrays. We also performed in vitro culture and identified the endothelial origin, as well as observing the functional characteristics in angiogenesis, of HEECs from the two different sources. Microarray analyses revealed distinct gene expression patterns and consistent up-regulation of certain endometrial endothelial marker genes across patient samples. More than 300 genes that exhibited $\geq 2$-fold differences were identified in tumor-associated HEECs. Pathway analysis showed that pathways of Cell cycle, Cell adhesion molecules (CAMs), focal adhesion, and extracellular matrix (ECM)-receptor interaction were obviously predominant. The results of the microarray analysis were confirmed by quantitative real-time PCR, immunohistochemistry, and/or Western blotting. Moreover, although the tumor-associated HEECs did not show faster proliferation than normal HEECs, they exhibited enhanced migration ability, potent invasiveness, and elevated tube formation in vitro. The present study shows that tumor and normal endothelium differ at the molecular level, and additional characterization of this gene expression database will provide
\end{abstract}

Correspondence to: Dr Ze-Qing Wen, Department of Obstetrics and Gynecology, Provincial Hospital affiliated to Shandong University, Jinan 250021, P.R. China

E-mail:wzq23800@yahoo.cn

Key words: endometrial cancer, human endometrial endothelial cells, angiogenesis, microarray analyses insights into the angiogenesis of endometrial cancers and might be of great benefit for finding potential therapeutic targets.

\section{Introduction}

Endometrial cancer is one of the most common malignancies of the female genital tract. Although early-stage endometrial cancer can be treated surgically, mortality in women with advanced disease has remained largely unchanged despite improvements in surgical technique, chemotherapy regimens, and radiation protocols (1-3). It is now well known that enhanced angiogenesis is relevant to an increased risk of metastasis and poor prognosis which makes it a very desirable therapeutic target in endometrial cancer (4-6).

Several studies indicated that tumor-associated vessels were structurally and functionally abnormal, with delayed maturation, increased permeability, and rapid proliferation $(7,8)$. Tumor-specific endothelial genes and normal endothelial genes were define in a small number of breast, colon, brain and ovarian cancers using microarray analyses (9-12). However, the endometrium is a tissue unique for its cyclic destruction and rapid regeneration of blood vessels. The angiogenic behavior of endometrium endothelial cells is expected to differ from those in other tissues. To date, only a few reports have described the isolation and characterization of endothelial cells of the endometrium (13-15). The molecular characterization of these isolated human endometrial endothelial cells (HEECs) has been limited to the evaluation of estradiol and progesterone receptors, the vascular endothelial growth factor receptor type 2 (VEGFR-2), and several select endothelial markers. This lack of data prompted us to carry out expression profiling on purified endothelial cells from invasive endometrial cancers and normal endometrium. Profiling expression changes that occur in the vasculature of endometrial cancer provide insight into the mechanisms underlying tumor vascular growth and also reveal attractive targets for antiangiogenic therapies.

In the present study, we immunopurified endothelial cells from freshly resected specimens of three endometrial cancers and three normal endometrial tissues and investigated the gene expression profile using microarrays. The subset of genes identified in this study may represent candidate genes involved in the angiogenesis and development of endometrial 
cancer. Moreover, we examined the growth characteristics and contrasted the capacity of immigration, invasiveness, and tube formation of isolated HEECs to find the different biological characteristics between tumor-specific and normal endothelium.

\section{Materials and methods}

Sample preparation. Fresh tissue samples of endometrial cancer were obtained from patients undergoing hysterectomies at the Shandong Tumor Hospital. The presence of endometrial cancer was confirmed by pathological diagnosis. Samples of normal endometrium were obtained from premenopausal women undergoing hysterectomy for benign gynecological diseases other than endometrial abnormalities. The patients selected for obtaining endometria had not been on hormonal medication for 6 months, and stages of the cycles were confirmed by histological examination and last menstruation period prior to the operations. Informed consent was obtained from all patients and the use of human specimens for these experiments was reviewed and approved by the committee of medical ethics, Shandong Tumor Hospital, Shandong province, P.R. China. The detailed information on case histories is listed in Table I. Since the endometrium is a tissue unique for its cyclic destruction and rapid regeneration of blood vessels, we chose patients with at same stage of the menstrual cycle to compare in this study.

The isolation and culture of HEECs were performed according to a previously reported procedure with a little modification (11). Three samples of endometrial cancer and three samples of normal endometria were used to isolate HEECs. The minced tissue was digested with $0.5 \%$ collagenase I at $37^{\circ} \mathrm{C}$ for $30 \mathrm{~min}$ followed by filtration through a metal mesh $(70 \mu \mathrm{m})$ screen for removal of the undigested tissue. Dual selection methods were used to ensure that any observed gene expression changes were pure HEECs. A number of negative selections were carried out, including red blood cell lysis $\left(\mathrm{NH}_{4} \mathrm{Cl}\right)$ and removal of monocytes, lymphocytes, and granulocytes using anti-CD14, anti-CD45, and anti-CD64 beads (DynaBeads, Dynal Biotech, Brown Deer, WI). Positive selection was performed repeatedly with mouse anti-human CD31 antibodies and goat anti-mouse IgG-coated Dynabeads as described. 5-10x10 $10^{6}$ positively isolated cells were used for RNA isolation after purity analysis by flow cytometry, and others were cultured in endothelium culture medium (Dulbecco's modified Eagle's medium supplemented with $20 \mathrm{mM}$ HEPES, $100 \mathrm{U} / \mathrm{ml}$ penicillin, $100 \mu \mathrm{g} / \mathrm{ml}$ streptomycin, $20 \%$ fetal bovine serum, $100 \mu \mathrm{g} / \mathrm{ml} \mathrm{ECGS}, 40 \mathrm{U} / \mathrm{ml}$ heparin and $40 \mathrm{U} / \mathrm{ml}$ insulin; Gibco BRL, Gaithersburg, MD) in a fibronectin-coated culture flask.

Flow cytometry. Before carrying out microarray analysis, we tested the purity of all samples with the endothelial cell markers CD31 and von Willebrand factor (vWF). Cells $\left(10^{5}\right)$ were incubated in PBS $/ 5 \%$ FBS with rabbit anti-human vWF monoclonal antibody or mouse anti-human CD31 at room temperature for $45 \mathrm{~min}$ (Santa Cruz Biotechnology, Inc., Santa Cruz, CA). After washing, the cells were incubated with FITC-labeled rat anti-rabbit or goat anti-mouse monoclonal antibody for $30 \mathrm{~min}$ and suspended in cold buffer. Flow cytometry was conducted on a FACScalibur (Becton Dickinson Labware, Franklin Lakes, NJ).

Immunofluorescence staining. Cells were plated on coverslips and fixed with cold $4 \%$ paraformaldehyde for $15 \mathrm{~min}$, permeabilized with $0.1 \%$ Triton X-100, then incubated with mouse anti-human CD31, CD34 or rabbit anti-human vWF for $1 \mathrm{~h}$ at room temperature. After washing, a fluorochromelabeled secondary antibody (1:100) was added for $1 \mathrm{~h} .4$ ', 6Diamidino-2-phenylindole was counterstained in some experiments, and the slides were mounted with antifade mounting medium (Santa Cruz Biotechnology, Inc.)

RNA isolation and oligonucleotide microarray analysis. Total RNA was harvested from endothelial cells using TRIzol (Invitrogen, Carlsbad, CA) and purified using the RNeasy Mini Kit and RNase-free DNase Set (Qiagen, Valencia, CA) according to the manufacturer's protocols. The quantity and quality of the purified RNA were assessed by OD260 and OD280 measurements on a spectrophotometer and the integrity was determined by formaldehyde denatured gel electrophoresis. The cDNA were synthesized by reverse transcription, purified, labeled with Cy3-dCTP and Cy5dCTP, and hybridized to Affymetrix Human Genome U133 Plus 2.0 Array containing 47000 transcripts according to the manufacturer's recommendations. The GeneChip arrays were washed and then stained (streptavidin-phycoerythrin) on an Affymetrix Fluidics Station 450 followed by scanning on a GeneChip Scanner 3000 and GeneChip Operating Software (Affymetrix, Santa Clara, CA). Array normalization and gene expression estimates were obtained using Affymetrix Microarray Suite 5.0 software (MAS5). Differential expression was determined using the combined basis of t-test with $\mathrm{P} \leq 0.05$ and fold changes of 2-fold.

Quantitative real-time polymerase chain reaction (PCR) validation. To evaluate the reliability of microarray results, ten genes were randomly selected for further confirmation by real-time PCR. Total RNA $(1 \mu \mathrm{g})$ was reverse transcribed in a total volume of $20 \mu 1$, and real-time PCR using SYBR green fluorescence was performed. Real-time quantitative polymerase chain reaction was performed on an ABI Prism 7000 Sequence Detection System using a SYBR Green RTPCR Kit (Applied Biosystems, Foster City, CA). The primers used for real-time PCR were listed in Table II. The protocol of real-time PCR was as follows: initiation with a $10 \mathrm{~min}$ denaturation at $95^{\circ} \mathrm{C}$, followed by 40 cycles of amplification at $95^{\circ} \mathrm{C}(10 \mathrm{sec})$ for denaturation, $55^{\circ} \mathrm{C}(10 \mathrm{sec})$ for annealing and $72^{\circ} \mathrm{C}$ for extension. All samples were run in triplicate. The real-time PCR amplification product was analyzed by melting curve analysis and 3\% agarose gel electrophoresis, respectively. To calculate the relative expression for each gene, the $2^{-\triangle \triangle C T}$ method was used, averaging the CT values for GAPDH for a single reference gene value (16).

Immunohistochemical staining. Five of the ten genes were randomly selected to be confirmed by immunohistochemistry, others were testified using Western blotting. Paraffin sections were antigen-retrieved, blocked in normal horse serum, and 


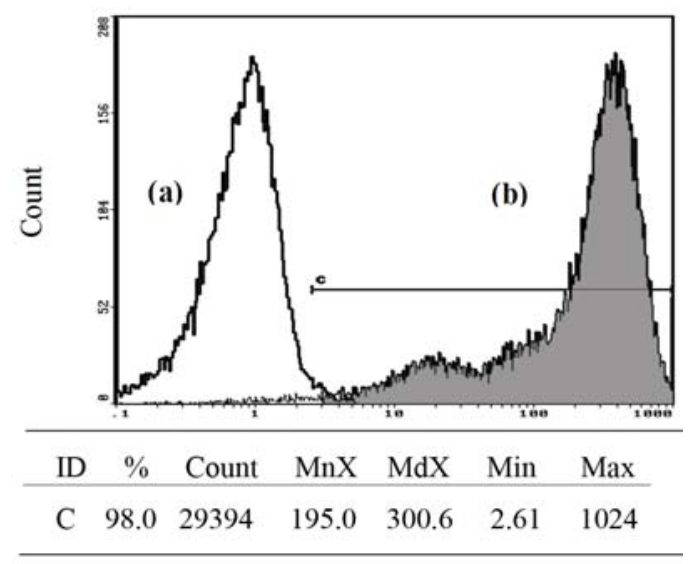

Figure 1. Detection of endothelial cell purity by flow cytometry. (a) Negative control; (b) HEECs purity in one sample of endometrial cancer. The immunopurification technique yielded endothelial cell purity of $98 \%$ in one sample of endometrial cancer.

incubated in the following antibodies: rabbit anti-endothelial cell-specific molecule 1(ESM1) at 1:100, rabbit anti-secreted phosphoprotein 1(SPP1) at 1:200 (BD Biosciences, Franklin Lakes, NJ), mouse anti-matrix metalloproteinase 10 (MMP10) at 1:50, anti-high-mobility group box 1 (HMGB1) at 1:200, or anti-Capping protein, gelsolin-like (CAPG) at 1:100 (Santa Cruz Biotechnology, Inc.) overnight at $4^{\circ} \mathrm{C}$. After three washes in PBS, sections were incubated with secondary antibody for $1 \mathrm{~h}$ at $37^{\circ} \mathrm{C}$. Positive reactions were detected by incubating the slides with stable 3,3-diaminobenzidine for 3-10 min. Sections were counterstained with Gill's hematoxylin for 30 to $60 \mathrm{sec}$. The intensity of protein expression in the endothelial cells was evaluated using Optimas 6.5 software.

Western blot analysis. Confluent cells were harvested and lysed with cold RIPA buffer. Total cell lysates were clarified by centrifugation $(14,000 \mathrm{rpm}, 20 \mathrm{~min})$ at $4^{\circ} \mathrm{C}$. Total protein concentration was determined by BCA Protein Assay kit (Pierce, Rockford, IL). Then $20 \mu \mathrm{g}$ of each soluble protein sample was separated by $10 \%$ or $15 \%$ SDS-polyacrylamide gel electrophoresis (PAGE) and transferred to a nitrocellulose membrane. After blocking with 5\% TBST-milk (20 mmol/1 Tris- $\mathrm{HCl}, 137 \mathrm{mM} \mathrm{NaCl}, 1.5 \%$ nonfat dry milk, and $0.1 \%$ Tween-20, pH 7.6), membranes were incubated with antiLAMB1 (1:1000), anti-VIM (1: 500), anti-MMP9 (1:500) (Santa Cruz Biotechnology), anti-ABCC3 (1:2500), antiCDC25B (1:1000), and anti-ß-actin (1:5000) (BD Biosciences, Franklin Lakes, NJ) antibodies overnight at $4^{\circ} \mathrm{C}$, respectively. Then the membranes were washed and incubated with horseradish peroxidase-labeled anti-rabbit or anti-mouse IgG antibody, respectively (Santa Cruz Biotech). After washing, the Western blot was developed using an enhanced chemiluminescence kit (Pierce, Rockford, IL). Detection was performed using the Dura West detection system (Pierce). Results were representative of four experiments.

Cell proliferation detection by MTT assay. HEECs in primary culture were detached by trypsin-EDTA and seeded in a 96-well plate $\left(10^{4}\right.$ cells/well) in three parallel wells each at $37^{\circ} \mathrm{C}$ in a $5 \% \mathrm{CO}_{2}$ humidified atmosphere. For non-cell control group, equal volume of medium was added. Cells were cultured for 24, 48, 72 and $96 \mathrm{~h}$ respectively, and viability was assessed using $20 \mu 1$ 3-(4, 5-dimethylthiazol-2-yl)-2, 5diphenyl tetrazolium bromide (MTT) $(15 \mathrm{mg} / \mathrm{ml}$, Sigma, St. Louis, USA) and incubated for a further $3 \mathrm{~h}$. The medium was removed and $150 \mu 1$ DMSO was added to each well. Optical density was read on a microplate reader at $570 \mathrm{~nm}$ using the DMSO as blank.

Wound healing assays of the endothelial monolayer. Confluent monolayers of endothelial cells were wounded using a micropipette tip $(1 \mathrm{ml})$, rinsed with growth medium. Wound closure was monitored for $16 \mathrm{~h}$ and photographed using a digital camera. For quantitative presentation of the data, the percentage of the repaired area was quantified by computerized analysis of the digitized images.

Cell invasion assay. Endothelial cell migration was investigated using a modified Transwell chamber system. HEECs $\left(2 \times 10^{5}\right)$ were seeded on Matrigel-coated membrane inserts with a pore size of $8 \mu \mathrm{m}$ (BD Bioscience, Heidelberg, Germany) in the presence of DMEM supplemented with $0.1 \%$ BSA. The lower chamber contained DMEM supplemented with $10 \%$ FCS, L-glutamine (10 mmol/l), basic fibroblast growth factor $(0.5 \mathrm{ng} / \mathrm{ml})$, epidermal growth factor $(0.05 \mathrm{ng} / \mathrm{ml})$ and endothelial cell growth-stimulating factor from bovine brain (ECGS/H, 0.2\%). After $20 \mathrm{~h}$ at $37^{\circ} \mathrm{C}$ in a humidified atmosphere with $5 \% \mathrm{CO}_{2}$, the cells on the upper side were scraped off with a rubber policeman and cells that had migrated into the lower compartment were fixed $(4 \%$ paraformaldehyde in PBS), stained with $\mathrm{H} \& \mathrm{E}$ and counted from five random high power fields at $\mathrm{x} 400$ magnification in each well.

Tube formation assay. Matrigel $(12.5 \mathrm{mg} / \mathrm{ml}$; Becton Dickinson, San Jose, CA) was thawed at $4^{\circ} \mathrm{C}$ and $50 \mu 1$ were quickly added to each well of a 96-well plate. Matrigelcontaining plates were allowed to incubate at $37^{\circ} \mathrm{C}$ for $30 \mathrm{~min}$ and then seeded with endothelial cells at a density of $2 \times 10^{4}$ cells/well. The wells were then incubated for $14 \mathrm{~h}$ at $37^{\circ} \mathrm{C}$. All of the experiments were carried out at least in triplicate.

Statistical analysis. The data are presented as mean \pm SD. Data were analyzed with SPSS 10.0 statistical software (SPSS, Chicago, IL). The statistical differences between means were evaluated using the Student's t-test. Differences between two groups were determined using a P-value. A value of $\mathrm{P} \leq 0.05$ was regarded as being statistically significant.

\section{Results}

Endothelial isolation and confirmation of cell purity. All samples were subjected to negative and positive immunoselection and $1-5 \times 10^{7}$ positively isolated cells were obtained from every sample. Flow cytometry revealed that the immunopurification technique yielded endothelial cell purity of $\geq 95 \%$ in all samples (Fig. 1 shows the HEEC purity in one sample of endometrial cancer). 

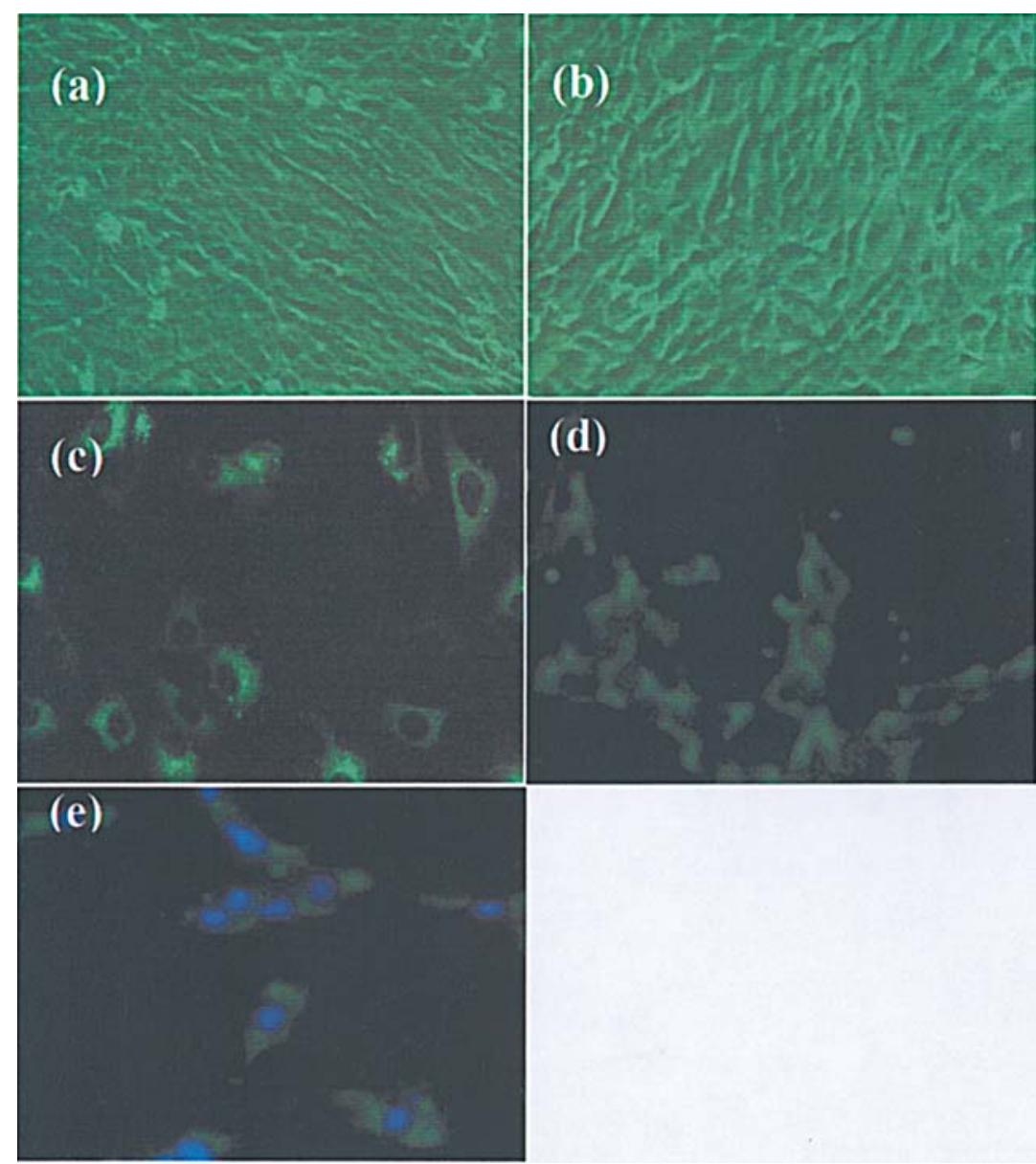

Figure 2. Morphology and characterization of purified endothelial cells. (a) Phase contrast photomicrograph of HEECs from normal endometria; (b) phase contrast photomicrograph of HEECs isolated from endometrial cancer. (c-e) Immunofluorescent staining: (c) vWF antigen; (d) CD31 antigen; (e) CD34 antigen. Original magnification. x200 (a and b), x400 (c-e).
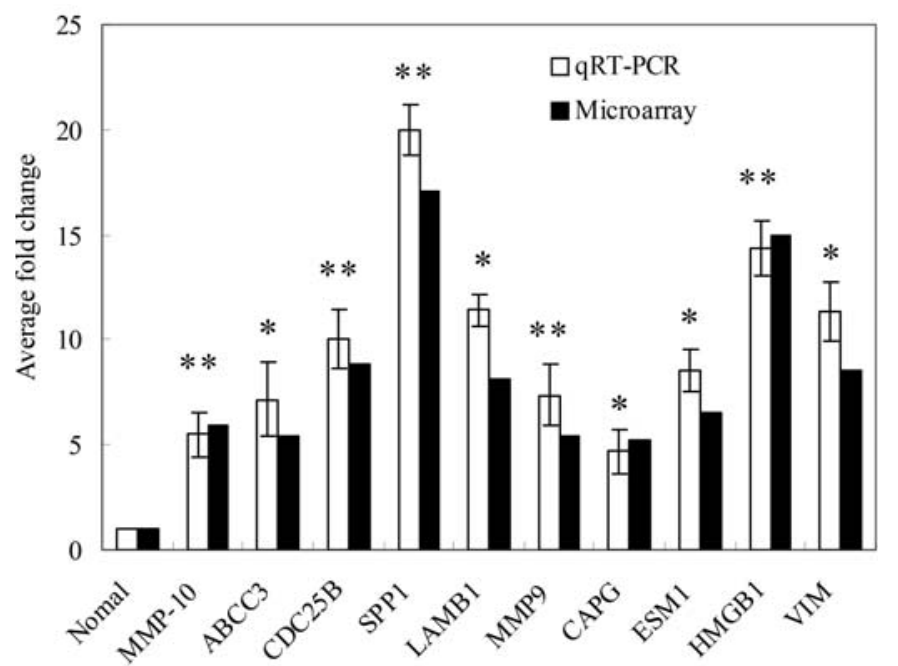

Figure 3. Quantitative real-time PCR validation of endothelial cell microarray data. Gene expression in 10 tumor isolates was calculated as a mean fold change relative to five normal endothelial specimens (normal, 1) using the 2-CT method. Real-time validation confirmed significant differential expression of 9 up-regulated genes, including MMP-10, ABCC3, CDC25B, SPP1, LAMB1, MMP9, CAPG, ESM1, HMGB1 and VIM, in tumor endothelial cells vs. normal isolates. ${ }^{*} \mathrm{P} \leq 0.05$ vs. control; ${ }^{* *} \mathrm{P} \leq 0.01$ vs. control.
Characterization of isolated endothelial cells. HEECs separated from normal and malignant endometrial tissue presented similar appearance in culture medium under phase contrast microscope. Cell cultures presented flattened monolayers, with typical cobblestone morphology and contact-inhibition (Fig. 2A and B). All purified cells were characterized as endothelial cells on the basis of expression of the classical endothelial markers vWF, CD31, and CD34 as shown by immunofluorescence examination (Fig. 2C-E). In addition, the cells were negative when stained with antibodies recognizing the epithelial cell markers (keratin 8 and 6A), hematopoietic cells (CD14 and CD45), and smooth muscle cell actin (data not shown).

Genes up-regulated in endometrial tumor-associated HEECs. Total RNA from purified endothelial cells was subjected to microarray analysis using the Affymetrix Human U133 Plus 2.0 GeneChip platform. A multivariate permutation $t$ test $(\mathrm{P} \leq 0.001)$ identified 317 genes that were differentially regulated $\geq 2$-fold in tumor-associated HEECs when compared with HEECs isolated from normal endometrium. There were 191 genes with $\geq 2$-fold increase in expression in tumor endothelium. Table III represents genes that were expressed at least 5-fold higher in tumor-associated HEECs. Several proteins involved in the extracellular matrix function, 
Table I. Case histories of subjects from whom endometria were used to isolate endothelial cells.

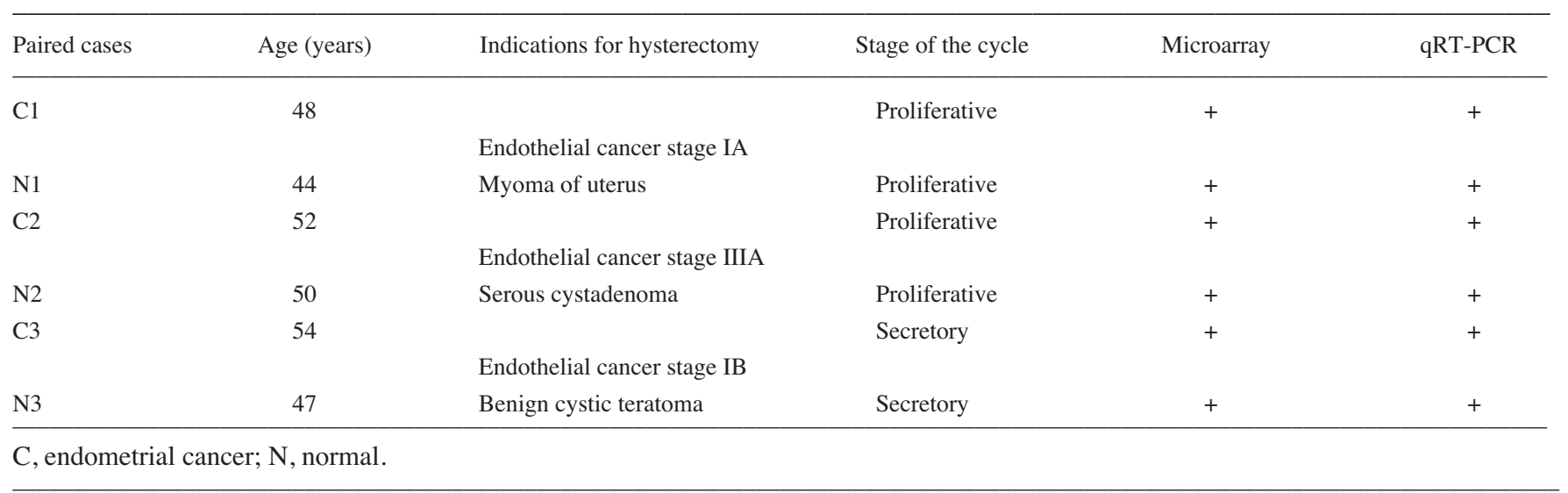

Table II. Sequences of primers used for qRT-PCR.

\begin{tabular}{|c|c|c|c|}
\hline Gene symbol & Gene bank ID & Primer sequence & Annealing temperature $\left({ }^{\circ} \mathrm{C}\right)$ \\
\hline MMP-10 & NM_002425 & $\begin{array}{l}\text { F 5'- CCTGATGTTGGTGGCTTCAGT -3' } \\
\text { R 5'- CTGGTGTATAATTCACAATCCTGTAGGT -3' }\end{array}$ & 60 \\
\hline $\mathrm{CDC} 25 \mathrm{~B}$ & S78187 & $\begin{array}{l}\text { F 5'-TCTCATCTGAGCGTGGGC-3' } \\
\text { P 5'-CTTCAGGCCTCGAAAGGC-3' }\end{array}$ & 57 \\
\hline SPP1 & NM_000582 & $\begin{array}{l}\text { F 5'- CTCCATTGACTCGAACGACTC -3 } \\
\text { R 5'- CAGGTCTGCGAAACTTCTTAGAT -3 }\end{array}$ & $60^{\prime}$ \\
\hline LAMB1 & NM_002291 & $\begin{array}{l}\text { F 5'-GGGTTCGTTAAGTTCCGTGT-3' } \\
\text { R 5'-CACTCACAAGGTTTGCATCC-3' }\end{array}$ & 58 \\
\hline $\mathrm{ABCC} 3$ & NM_003786 & $\begin{array}{l}\text { F 5'-GCTCCAAGATCCTTTTAGCCAA-3' } \\
\text { R 5'-GCCAAGATGAGGGCAGAGAGTA-3' }\end{array}$ & 58 \\
\hline $\begin{array}{l}\text { MMP9 } \\
\text { ? }\end{array}$ & NM_004994 & $\begin{array}{l}\text { F 5'-TGCCTGCAACGTGAACATCT-3 } \\
\text { R 5'-CACTTGTCGGCGATAAGGAA-3' }\end{array}$ & 60 \\
\hline ESM1 & NM_007036 & $\begin{array}{l}\text { F 5'-CAGGCATGGATGGCATGAAG-3' } \\
\text { R 5'-CTGACTGGCAGTTGCAGGTCTC-3' }\end{array}$ & 57 \\
\hline HMGB1 & NM_002128 & $\begin{array}{l}\text { F 5'-AATGGGCTGATAAAAGGTTTTG-3' } \\
\text { R 5'-CTAACCCTGCTGTTCGCTTG-3' }\end{array}$ & 59 \\
\hline VIM & NM_003380 & $\begin{array}{l}\text { F 5'-GTTTGGTCGCATATCGCAAC-3' } \\
\text { R 5'-AATGCGCAGCACCAGGATAG-3' }\end{array}$ & 60 \\
\hline CAPG & NM_001747 & $\begin{array}{l}\text { F 5'-CTCACAGCTGACAAGGCAAA-3 } \\
\text { R 5'-CCACCCTCATTTCCAGTCC-3' }\end{array}$ & 60 \\
\hline GAPDH & NM_002046 & $\begin{array}{l}\text { F 5'-GGGAGCCAAAAGGGTCATCATCTC-3' } \\
\text { R 5'-CCATGCCAGTGAGCTTCCCGTTC-3' }\end{array}$ & 57 \\
\hline
\end{tabular}

F, forward primer; $R$, reverse primer.

such as SPP1, MMP9, LAMB1, MMP10, LOX, and LGALS3BP, had increased expression in tumor vasculature by changes of 17.1-, 5.4-, 8.2-, 5.9-, 5.9-, and 9.0-fold, respectively. Several proteins responsible for actin cytoskeleton organization and regulation, such as CAPG, CAPZA1 and TMSB10, were up-regulated by 5.1-, 8.2- and 5.6-fold, respectively. MAPRE1, CDC25B and CCNB2, genes correlating with regulation of the cell cycle, were also elevated in tumor endothelium.
Genes down-regulated in endometrial cancer endothelium. The reduction of gene expression in tumor versus normal vasculature may reveal a gene function to suppress tumor and/or vascular growth. We also identified genes that were down-regulated in endothelial cells derived from endometrial cancer tissue. There were 126 genes with $\geq 2$-fold decrease in expression in tumor endothelium, with 25 decreased at least 5 -fold (Table IV). Several genes with potential antiangiogenic or antiproliferative roles, such as Cyclin-dependent 
Table III. Genes up-regulated by 5-fold in the tumor-associated endothelium.

\begin{tabular}{|c|c|c|c|c|c|}
\hline GeneBank ID & Name & Description & Fold & $\begin{array}{l}\text { Chromosomal } \\
\text { location }\end{array}$ & Function \\
\hline L25081 & RHOC & Ras homolog gene family, member C & 7.452 & $1 \mathrm{p} 13.1$ & $\begin{array}{l}\text { Plays a role in I- } \kappa \text { B kinase NF- } \kappa \text { B } \\
\text { cascade and small GTPase mediated signal } \\
\text { transduction }\end{array}$ \\
\hline NM_000582 & SPP1 & $\begin{array}{l}\text { Secreted phosphoprotein } 1 \text { (osteopontin, } \\
\text { bone sialoprotein I early T-lymphocyte } \\
\text { activation 1) }\end{array}$ & 17.087 & $4 q 21-q 25$ & $\begin{array}{l}\text { Growth factor activity; cell-cell signaling } \\
\text { skeletal development; regulation of cell } \\
\text { proliferation; cell motility }\end{array}$ \\
\hline NM_001546 & ID4 & $\begin{array}{l}\text { Inhibitor of DNA binding } 4 \text {, } \\
\text { dominant negative helix-loop-helix } \\
\text { protein }\end{array}$ & 8.744 & $6 \mathrm{p} 22-\mathrm{p} 21$ & $\begin{array}{l}\text { Regulation of transcription from RNA } \\
\text { polymerase II; transcription cofactor activity }\end{array}$ \\
\hline NM_001549 & IFIT4 & $\begin{array}{l}\text { Interferon-induced protein with } \\
\text { tetratricopeptide repeats } 4\end{array}$ & 7.014 & $10 \mathrm{q} 24$ & Unknown \\
\hline NM_001618 & PARP1 & $\begin{array}{l}\text { Poly (ADP-ribose) polymerase } \\
\text { family, member } 1\end{array}$ & 5.553 & $1 q 41-q 42$ & $\begin{array}{l}\text { Fas pathway and stress induction of } \\
\text { HSP regulation; response to DNA damage } \\
\text { stimulus; DNA repair; transcription from RNA } \\
\text { polymerase II promoter }\end{array}$ \\
\hline NM_001747 & CAPG & $\begin{array}{l}\text { Capping protein (actin filament), } \\
\text { gelsolin-like }\end{array}$ & 5.177 & $2 \mathrm{p} 11.2$ & $\begin{array}{l}\text { Actin cytoskeleton organization and } \\
\text { biogenesis; actin filament-based process }\end{array}$ \\
\hline NM_001781 & CD69 & CD69 molecule & 8.352 & $12 \mathrm{p} 13-\mathrm{p} 12$ & Cell surface receptor linked signal transduction \\
\hline NM_002128 & HMGB1 & High-mobility group box 1 & 5.008 & $13 q 12$ & $\begin{array}{l}\text { Cell cycle; establishment and or maintenance of } \\
\text { chromatin architecture }\end{array}$ \\
\hline NM_002210 & ITGAV & $\begin{array}{l}\text { Integrin, } \alpha \mathrm{V} \text { (vitronectin receptor, } \\
\alpha \text { polypeptide, antigen CD51) }\end{array}$ & 8.667 & $2 \mathrm{q} 31-\mathrm{q} 32$ & $\begin{array}{l}\text { Cell adhesion molecules (CAMs); regulation } \\
\text { of actin cytoskeleton; focal adhesion; } \\
\text { ECM-receptor interaction }\end{array}$ \\
\hline NM_002317 & LOX & Lysyl oxidase & 5.861 & $5 q 23.2$ & Lysyl oxidase \\
\hline NM_002425 & MMP10 & $\begin{array}{l}\text { Matrix metalloproteinase } \\
10 \text { (stromelysin 2) }\end{array}$ & 5.881 & $11 \mathrm{q} 22.3$ & $\begin{array}{l}\text { Involved in the breakdown of extracellular matrix } \\
\text { in embryonic development, reproduction, tissue } \\
\text { remodeling, and disease processes }\end{array}$ \\
\hline NM_003039 & SLC2A5 & Solute carrier family 2 , member 5 & 8.026 & $1 \mathrm{p} 36.2$ & Carbohydrate metabolism; plasma membrane \\
\hline NM_003380 & VIM & Vimentin & 8.576 & $10 \mathrm{p} 13$ & $\begin{array}{l}\text { Cell communication; structural constituent of } \\
\text { cytoskeleton; }\end{array}$ \\
\hline NM_003404 & YWHAB & $\begin{array}{l}\text { Tyrosine } 3 \text {-monooxygenase/ } \\
\text { tryptophan } 5 \text {-monooxygenase } \\
\text { activation protein, } \beta \text { polypeptide }\end{array}$ & 6.652 & $20 \mathrm{q} 13.1$ & $\begin{array}{l}\text { Cell cycle; smooth muscle contraction; calcium } \\
\text { regulation in cardiac cells; }\end{array}$ \\
\hline NM_003457 & ZNF207 & Zinc finger protein 207 & 9.322 & $17 \mathrm{q} 11.2$ & Unknown \\
\hline NM_003786 & $\mathrm{ABCC} 3$ & $\begin{array}{l}\text { ATP-binding cassette, } \\
\text { sub-family C (CFTR/ MRP), member } 3\end{array}$ & 5.449 & $17 \mathrm{q} 22$ & $\begin{array}{l}\text { ATPase activity, transmembrane movement of } \\
\text { substances; nuclear receptors in ipid metabolism } \\
\text { and toxicity }\end{array}$ \\
\hline NM_003816 & ADAM9 & $\begin{array}{l}\text { ADAM metallopeptidase } \\
\text { domain } 9 \text { (meltrin } \gamma)\end{array}$ & 14.611 & $8 \mathrm{p} 11.23$ & $\begin{array}{l}\text { Metalloendopeptidase activity; } \\
\text { metallopeptidase activity; }\end{array}$ \\
\hline NM_004390 & CTSH & Cathepsin H & 5.145 & $15 q 24-q 25$ & Cysteine-type peptidase activity; lytic vacuole \\
\hline NM_004994 & MMP9 & $\begin{array}{l}\text { Matrix metallopeptidase } 9 \text {, } \\
\text { (gelatinase B, } 92 \mathrm{kDa} \text { gelatinase } \\
92 \mathrm{kDa} \text { type IV collagenase) }\end{array}$ & 5.437 & $20 q 11.2-13.1$ & $\begin{array}{l}\text { Leukocyte transendothelial migration } \\
\text { inhibition of Matrix Metalloproteinases; } \\
\text { extracellular matrix }\end{array}$ \\
\hline NM_005192 & CDKN3 & $\begin{array}{l}\text { Cyclin-dependent kinase inhibitor } 3 \\
\text { (CDK2-associated dual specificity } \\
\text { phosphatase) }\end{array}$ & 8.358 & $14 q 22$ & $\begin{array}{l}\text { Regulation of cell cycle; regulation of cell } \\
\text { proliferation; dephosphorylation }\end{array}$ \\
\hline NM_005567 & $\begin{array}{l}\text { LGAL } \\
\text { S3BP }\end{array}$ & $\begin{array}{l}\text { Lectin, galactoside-binding, } \\
\text { soluble, } 3 \text { binding protein }\end{array}$ & 9.038 & $17 q 25$ & Extracellular space; extracellular matrix \\
\hline NM_005596 & NFIB & Nuclear factor I/B & 8.020 & $9 \mathrm{p} 24.1$ & DNA replication \\
\hline
\end{tabular}


Table III. (Continued)

\begin{tabular}{|c|c|c|c|c|c|}
\hline GeneBank ID & Name & Description & Fold & $\begin{array}{l}\text { Chromosomal } \\
\text { location }\end{array}$ & Function \\
\hline NM_006135 & CAPZA1 & $\begin{array}{l}\text { Capping protein (actin filament) } \\
\text { muscle Z-line, } \alpha 1\end{array}$ & 8.179 & $1 \mathrm{p} 13.2$ & $\begin{array}{l}\text { Actin cytoskeleton } \\
\text { organization and biogenesis; cell motility }\end{array}$ \\
\hline NM_006290 & TNFAIP3 & $\begin{array}{l}\text { Tumor necrosis factor, } \\
\alpha \text {-induced protein } 3\end{array}$ & 6.913 & $6 q 23$ & $\begin{array}{l}\text { Regulation of metabolism; ubiquitin } \\
\text { cycle; negative regulation of apoptosis }\end{array}$ \\
\hline NM_006597 & HSPA8 & Heat shock $70 \mathrm{kDa}$ protein 8 & 11.084 & $11 \mathrm{q} 24.1$ & $\begin{array}{l}\text { Circadian exercise; protein folding; MAPK } \\
\text { signaling pathway }\end{array}$ \\
\hline NM_007022 & $\begin{array}{l}\text { CYB } \\
561 \mathrm{D} 2\end{array}$ & Putative tumor suppressor & 6.017 & $3 \mathrm{p} 21.3$ & $\begin{array}{l}\text { M phase of mitotic cell cycle; ubiquitin- } \\
\text { dependent protein catabolism; }\end{array}$ \\
\hline NM_007036 & ESM1 & Endothelial cell-specific molecule 1 & 6.496 & $5 q 11.2$ & $\begin{array}{l}\text { Growth factor activity; cellular } \\
\text { morphogenesis; regulation of growth }\end{array}$ \\
\hline NM_012325 & MAPRE1 & $\begin{array}{l}\text { Microtubule-associated protein, } \\
\text { RP/EB family, member } 1\end{array}$ & 6.048 & $20 q 11.1-11.23$ & Cell proliferation; regulation of cell cycle \\
\hline NM_014937 & INPP5F & Inositol polyphosphate-5- phosphatase F & 6.489 & $10 q 26.11$ & Unknown \\
\hline NM_015507 & EGFL6 & EGF-like-domain, multiple 6 & 11.079 & $\mathrm{Xp} 22$ & $\begin{array}{l}\text { Regulation of cell cycle, proliferation, and } \\
\text { developmental processes; extracellular space }\end{array}$ \\
\hline NM_016076 & C1orf121 & Chromosome 1 open reading frame 121 & 5.213 & $1 \mathrm{q} 44$ & Unknown \\
\hline NM_016433 & GLTP & Glycolipid transfer protein & 6.365 & $12 q 24.11$ & Glycolipid transporter activity \\
\hline NM_017443 & POLE3 & $\begin{array}{l}\text { Polymerase (DNA directed), } \\
\varepsilon 3 \text { (p17 subunit) }\end{array}$ & 6.355 & $9 \mathrm{q} 33$ & $\begin{array}{l}\text { Nucleotidyltransferase } \\
\text { activity; DNA replication }\end{array}$ \\
\hline NM_017549 & EPDR1 & Ependymin related protein 1 & 6.369 & $7 \mathrm{p} 14.1$ & $\begin{array}{l}\text { A type II transmembrane protein } \\
\text { similar to protocadherins } \\
\text { cell adhesion molecules; calcium } \\
\text { dependent cell adhesion }\end{array}$ \\
\hline NM_020644 & TMEM9B & $\begin{array}{l}\text { TMEM9 domain family, } \\
\text { member B }\end{array}$ & 10.488 & $11 \mathrm{p} 15.3$ & 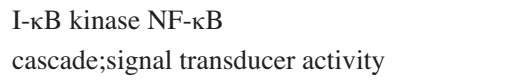 \\
\hline NM_025130 & HKDC1 & $\begin{array}{l}\text { Hexokinase domain } \\
\text { containing } 1\end{array}$ & 6.018 & $10 \mathrm{q} 21.3$ & $\begin{array}{l}\text { Energy derivation by oxidation of } \\
\text { organic compounds; kinase activity }\end{array}$ \\
\hline NM_030796 & ECOP & $\begin{array}{l}\text { EGFR-coamplified and } \\
\text { overexpressed protein }\end{array}$ & 8.054 & $7 \mathrm{p} 11.2$ & Unknown \\
\hline NM_030945 & CTRP3 & $\begin{array}{l}\text { Complement-c1q tumor } \\
\text { necrosis factor-related protein; } \\
\text { likely ortholog of mouse CORS26 }\end{array}$ & 7.486 & $5 \mathrm{p} 13-\mathrm{p} 12$ & $\begin{array}{l}\text { Inorganic anion transport; } \\
\text { anion transport }\end{array}$ \\
\hline NM_032376 & TMEM101 & Transmembrane protein 101 & 5.850 & $17 q 21.31$ & $\begin{array}{l}\text { I-кB kinase NF-кB } \\
\text { cascade; signal transducer activity }\end{array}$ \\
\hline NM_033380 & COL4A5 & Collagen, type IV, $\alpha 5$ & 8.484 & $\mathrm{Xq} 22$ & $\begin{array}{l}\text { Extracellular protein; encodes one } \\
\text { of the six subunits of type IV } \\
\text { collagen, the major structural } \\
\text { component of basement membranes. }\end{array}$ \\
\hline NM_138376 & TTC5 & Tetratricopeptide repeat domain 5 & 6.564 & $14 \mathrm{q} 11.2$ & Known as Strap \\
\hline NM_138455 & CTHRC1 & $\begin{array}{l}\text { Collagen triple helix repeat } \\
\text { containing } 1\end{array}$ & 6.745 & $8 q 22.3$ & Inorganic anion transport \\
\hline NM_138462 & ZMYND19 & $\begin{array}{l}\text { Zinc finger, MYND-type } \\
\text { containing } 19\end{array}$ & 8.646 & $9 q 34.3$ & May associate with tubulin \\
\hline NM_17886 & CKLFSF8 & $\begin{array}{l}\text { Chemokine-like factor } \\
\text { superfamily } 8\end{array}$ & 6.335 & $3 \mathrm{p} 22.3$ & $\begin{array}{l}\text { Regulates EGF-induced signaling; } \\
\text { regulates cell proliferation }\end{array}$ \\
\hline NM_212539 & PRKCD & Protein kinase $\mathrm{C}, \delta$ & 5.515 & $3 \mathrm{p} 21.31$ & $\begin{array}{l}\text { Fc } \varepsilon \text { RI signaling pathway; } \\
\text { Tight junction; skeletal } \\
\text { development ; enzyme inhibitor } \\
\text { activity positive regulation of cell }\end{array}$ \\
\hline NR_001562 & ANXA2 & Annexin A2 & 8.745 & $15 q 21-q 22$ & Proliferation; regulation of cell \\
\hline S78187 & $\mathrm{CDC} 25 \mathrm{~B}$ & Cell division cycle $25 \mathrm{~B}$ & 8.788 & $20 \mathrm{p} 13$ & $\begin{array}{l}\text { cycle; cell division; MAPK } \\
\text { signaling pathway }\end{array}$ \\
\hline
\end{tabular}


Table IV. Genes down-regulated by 5-fold in the tumor-associated endothelium.

\begin{tabular}{|c|c|c|c|c|c|}
\hline GeneBank ID & Name & Description & Fold & $\begin{array}{l}\text { Chromosomal } \\
\text { location }\end{array}$ & Function \\
\hline NM_000077 & CDKN2A & Cyclin-dependent kinase inhibitor 2A & 0.138 & $9 \mathrm{p} 21$ & $\begin{array}{l}\text { Negative regulation of cell proliferation; enzyme } \\
\text { inhibitor activity; cell cycle }\end{array}$ \\
\hline NM_000090 & COL3A1 & Collagen, type III, $\alpha 1$ & 0.044 & $2 q 31$ & $\begin{array}{l}\text { Inorganic anion transport; Inflammatory } \\
\text { Response Pathway }\end{array}$ \\
\hline NM_000765 & CYP3A7 & $\begin{array}{l}\text { Cytochrome P450, } \\
\text { family } 3 \text {, subfamily A, polypeptide } 7\end{array}$ & 0.072 & $7 q 21-q 22.1$ & $\begin{array}{l}\text { Microsome; response to chemical substance; } \\
\text { oxidoreductase activity }\end{array}$ \\
\hline NM_001349 & DARS & Aspartyl-tRNA synthetase & 0.147 & $2 q 21.3$ & $\begin{array}{l}\text { protein complex assembly; translation; ligase } \\
\text { activity; Alanine and aspartate metabolism }\end{array}$ \\
\hline NM_001532 & SLC29A2 & Solute carrier family 29 , member 2 & 0.159 & $11 \mathrm{q} 13$ & Cell proliferation \\
\hline NM_001904 & CTNNB1 & $\begin{array}{l}\text { catenin (cadherin-associated protein), } \\
ß 1,88 \mathrm{kDa}\end{array}$ & 0.144 & $3 \mathrm{p} 21$ & $\begin{array}{l}\text { Cell to Cell Adhesion Signaling; WNT } \\
\text { Signaling Pathway; regulation of transcription } \\
\text { from RNA polymerase II promoter; leukocyte } \\
\text { transendothelial migration }\end{array}$ \\
\hline NM_002461 & MVD & Mevalonate (diphospho) decarboxylase & 0.124 & $16 \mathrm{q} 24.3$ & $\begin{array}{l}\text { Lipid biosynthesis; lyase activity; kinase activity; } \\
\text { steroid metabolism; }\end{array}$ \\
\hline NM_002573 & PAFAH1B3 & $\begin{array}{l}\text { Platelet-activating factor acetylhydrolase, } \\
\text { isoform Ib, } \gamma \text { subunit }(29 \mathrm{kD})\end{array}$ & 0.052 & $19 \mathrm{q} 13.1$ & $\begin{array}{l}\text { Soluble fraction; carboxylic ester hydrolase } \\
\text { activity }\end{array}$ \\
\hline NM_002865 & RAB2A & RAB2, member RAS oncogene family & 0.156 & $8 \mathrm{q} 12.1$ & $\begin{array}{l}\text { Intracellular protein transport; small GTPase } \\
\text { mediated signal transduction }\end{array}$ \\
\hline NM_003017 & SFRS3 & Splicing factor, arginine/serine-rich 3 & 0.166 & $6 \mathrm{p} 21$ & RNA splicing \\
\hline NM_003587 & DHX16 & DEAD/H box polypeptide 16 & 0.184 & $6 \mathrm{p} 21.3$ & $\begin{array}{l}\text { mRNA processing; RNA splicing; helicase } \\
\text { activity; regulation of cell cycle }\end{array}$ \\
\hline NM_003620 & PPM1D & $\begin{array}{l}\text { Protein phosphatase } 1 \mathrm{D} \\
\text { magnesium-dependent, } \delta \text { isoform }\end{array}$ & 0.054 & $17 \mathrm{q} 23.2$ & $\begin{array}{l}\text { Phosphoprotein phosphatase activity; } \\
\text { dephosphorylation; negative regulation of cell } \\
\text { proliferation; regulation of cell cycle }\end{array}$ \\
\hline NM_005738 & ARL4A & ADP-ribosylation factor-like 4 & 0.108 & $7 \mathrm{p} 21-\mathrm{p} 15.3$ & $\begin{array}{l}\text { GTPase activity; small GTPase mediated signal } \\
\text { transduction }\end{array}$ \\
\hline NM_006191 & PA2G4 & Proliferation-associated 2G4, $38 \mathrm{kD}$ & 0.188 & $12 q 13.2$ & Metallopeptidase activity; cell proliferation; \\
\hline NM_006770 & MARCO & $\begin{array}{l}\text { Macrophage receptor with } \\
\text { collagenous structure }\end{array}$ & 0.041 & $2 q 12-q 13$ & Inorganic anion transport \\
\hline NM_006821 & ACOT2 & acyl-CoA thioesterase 2 & 0.157 & $14 \mathrm{q} 24.3$ & $\begin{array}{l}\text { Lipid metabolism; coenzyme metabolism; } \\
\text { fatty acid metabolism }\end{array}$ \\
\hline NM_015922 & NSDHL & $\begin{array}{l}\text { NAD }(\mathrm{P}) \text { dependent steroid } \\
\text { dehydrogenase-like; H105e } 3\end{array}$ & 0.107 & $\mathrm{Xq} 28$ & $\begin{array}{l}\text { Lipid biosynthesis; cholesterol } \\
\text { biosynthesis; steroid metabolism; }\end{array}$ \\
\hline NM_019903 & ADD3 & Adducin $3(\gamma)$ & 0.104 & $10 \mathrm{q} 24.2-\mathrm{q} 24.3$ & $\begin{array}{l}\text { Structural constituent of cytoskeleton; } \\
\text { calmodulin binding; }\end{array}$ \\
\hline NM_020401 & NUP107 & Nuclear pore complex protein & 0.197 & $12 \mathrm{q} 15$ & $\begin{array}{l}\text { Protein transport; nuclear transport; } \\
\text { endomembrane system; }\end{array}$ \\
\hline NM_024027 & COLEC11 & Collectin sub-family member 11 & 0.107 & $2 \mathrm{p} 25.3$ & $\begin{array}{l}\text { Inorganic anion transport; humoral } \\
\text { immune response; carbohydrate binding }\end{array}$ \\
\hline NM_032603 & LOXL3 & Lysyl oxidase-like 3 & 0.091 & $2 \mathrm{p} 13$ & $\begin{array}{l}\text { Formation of crosslinks in collagens and elastin; } \\
\text { may play a role in developmental regulation, } \\
\text { senescence, tumor suppression, cell growth } \\
\text { control, and chemotaxis }\end{array}$ \\
\hline NM_145183 & PYCARD & $\begin{array}{l}\text { Apoptosis-associated speck-like } \\
\text { protein containing a CARD }\end{array}$ & 0.098 & $16 \mathrm{p} 12-\mathrm{p} 11.2$ & $\begin{array}{l}\text { Enzyme activator } \\
\text { activity; induction of apoptosis; positive } \\
\text { regulation of apoptosis }\end{array}$ \\
\hline NM_206917 & NGFRAP1 & $\begin{array}{l}\text { Nerve growth factor receptor } \\
\text { (TNFRSF16) associated protein } 1\end{array}$ & 0.133 & $\mathrm{Xq} 22.2$ & Apoptosis \\
\hline NM_207043 & ENSA & Endosulfine $\alpha$ & 0.099 & $1 \mathrm{q} 21.2$ & Response to chemical substance \\
\hline
\end{tabular}




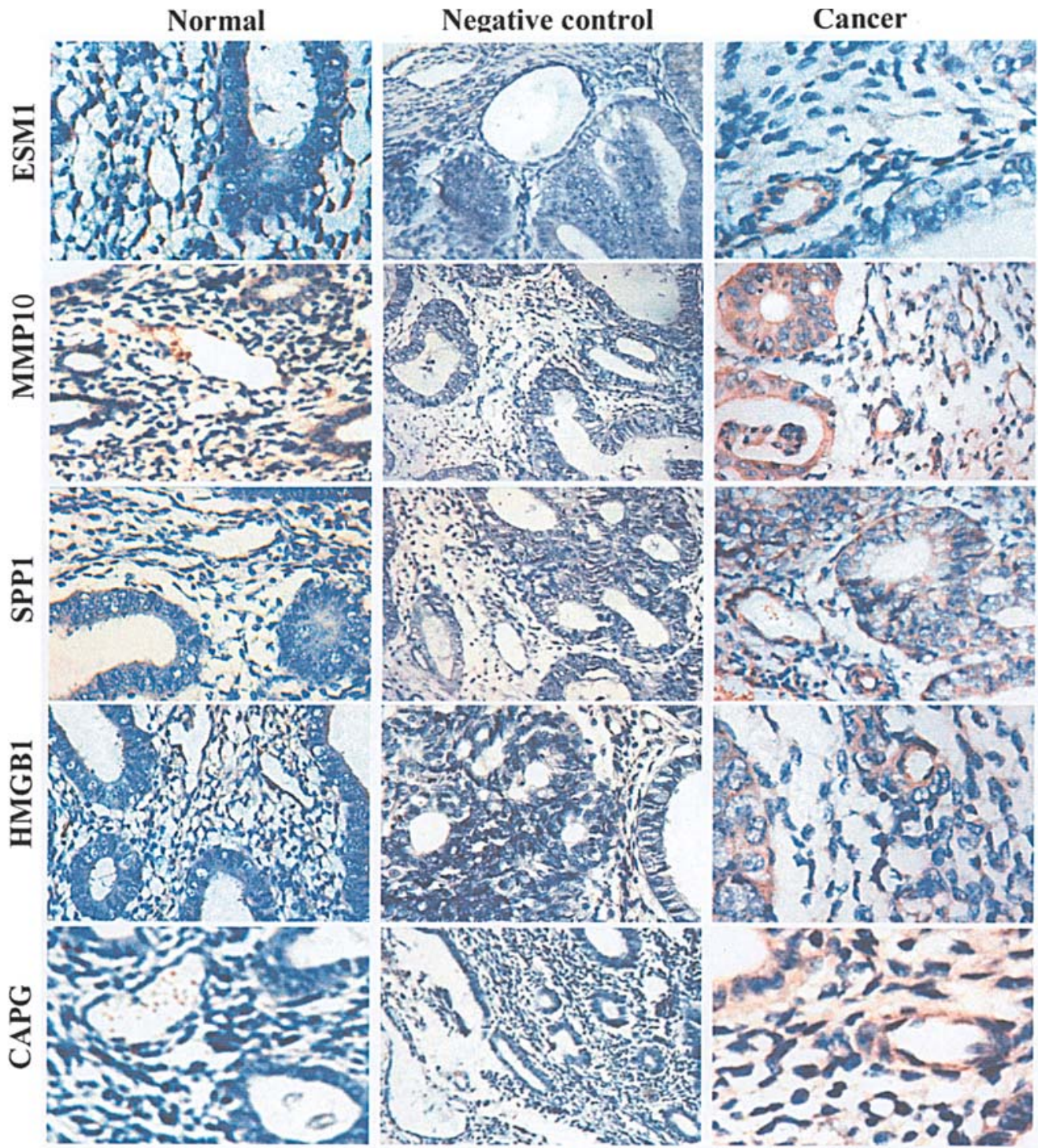

Figure 4. Immunohistochemical staining for ESM1, MMP10, SPP1, HMGB1, and CAPG in human normal endometria and endometrial cancers. All photomicrographs were taken at original magnification (x200 or $\times 400)$.

kinase inhibitor 2A (CDKN2A) and Solute carrier family 29 member 2 (SLC29A2), were down-regulated by 7.2- and 6.3fold, respectively. Nerve growth factor receptor associated protein 1 (NGFRAP1) and apoptosis-associated speck-like protein containing a CARD (PYCARD), genes responsible for the induction of apoptosis, were down-regulated by 7.5and 9.2-fold, respectively. Catenin $\beta 1(\mathrm{CTNN} ß 1)$, an important factor of cell to cell adhesion signaling, was decreased by 6.9 -fold.

Pathway analysis. All 317 differentially expressed genes were analyzed using Molecular Annotation System 2.0 (MAS 2.0, www.capitalbio.com) which integrates three pathway resources-KEGG, BioCarta and GenMAPP. The pathways are ranked with statistical significance by calculating their P-values based on hypergeometric distribution (17). Table V lists the significant pathways associated with cell survival. Among these, the pathways of cell cycle, cell adhesion molecules (CAMs), focal adhesion, and extracellular matrix (ECM)-receptor interaction have predominated.
Validation of gene expression alterations. To show the reproducibility of the microarray analysis, 10 genes were selected at random, spanning a range of fold-changes (5.229.1, Fig. 3). The microarray analysis identified MMP10 (13.8-fold), ABCC3 (5.4-fold), CDC25B (8.8-fold), SPP1 (29.1-fold), LAMB1 (8.2-fold), MMP9 (18.4-fold), CAPG (5.2-fold), ESM1 (6.5-fold), HMGB1 (15.0-fold), and VIM (8.6-fold) as being significantly increased in tumorassociated HEECs, and these changes were validated by realtime RT-PCR. Fig. 3 shows relative gene expression compared with normal HEECs. These data provide important confirmation of the gene expression alterations identified by the microarray analysis.

Immunohistochemical staining and Western blot analysis. Increased expression of ESM1, MMP10, SPP1, HMGB1, and CAPG was confirmed at the protein level by immunohistochemical peroxidase staining in the tumor-associated vascular endothelia (Fig. 4) in all samples of endometrial cancer. A negative staining procedure (the same staining 


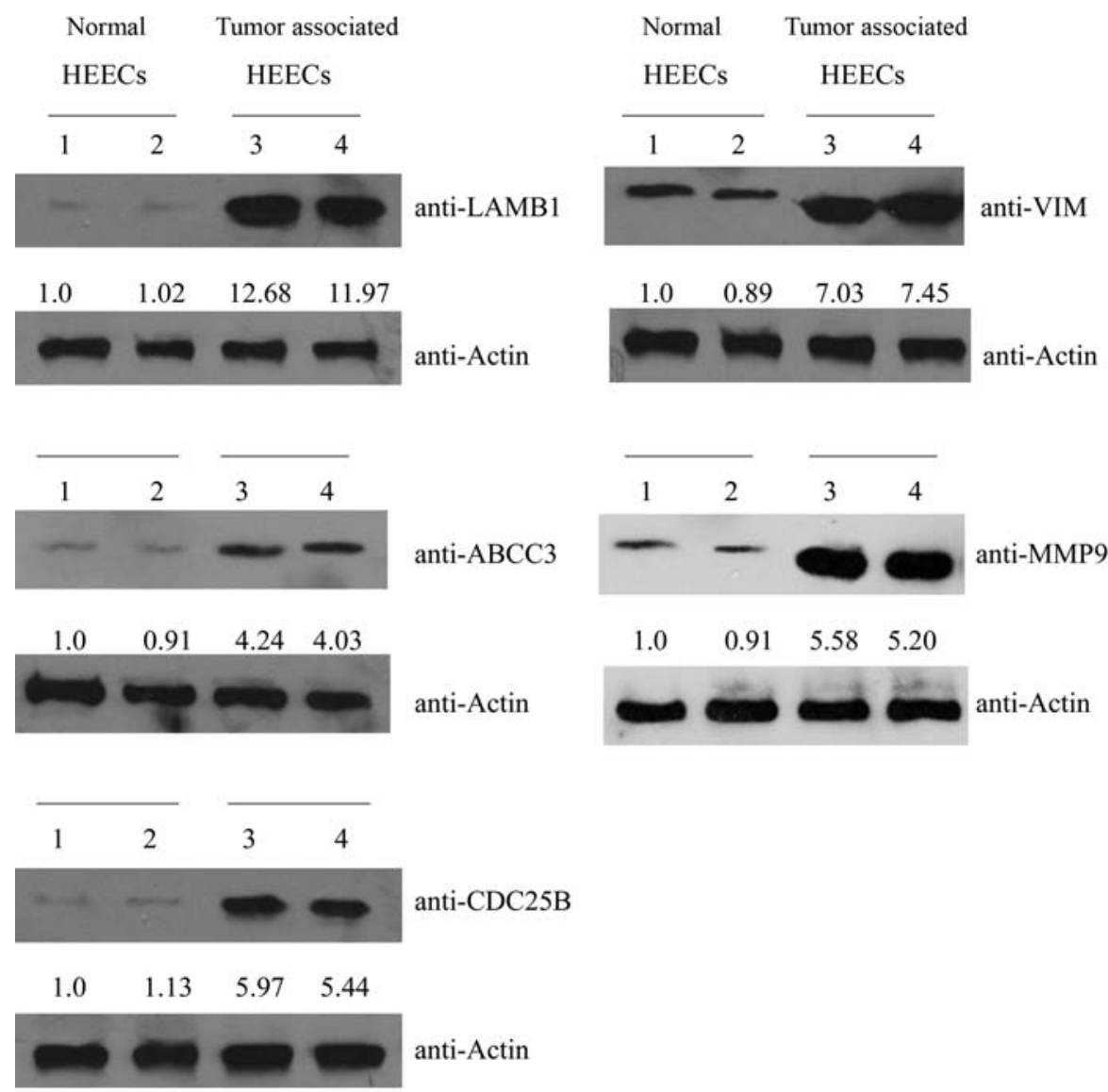

Figure 5. Western blot showing LAMB1, VIM, ABCC3, MMP9 and CDC25B protein in normal HEECs and tumor-associated HEECs. Representative experiments are shown.

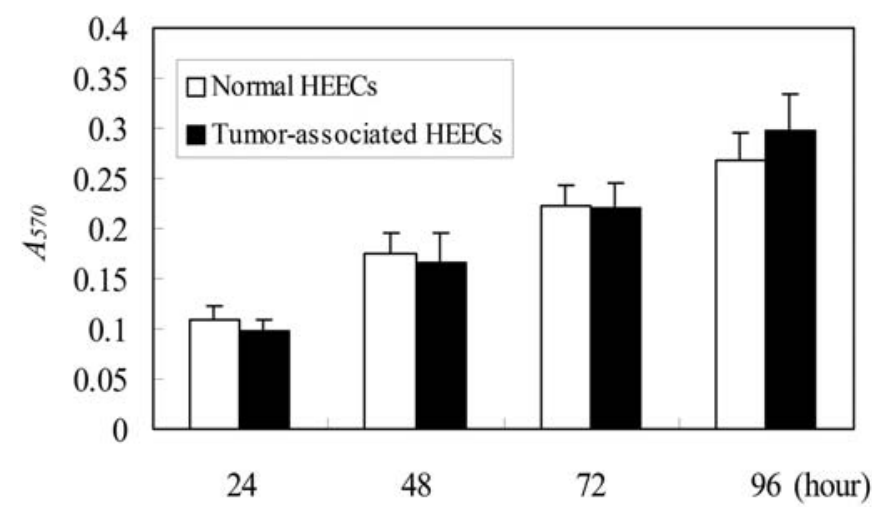

Figure 6. Proliferation assay of normal HEECs and tumor-associated HEECs. After cells were cultured for 24, 48, 72 and $96 \mathrm{~h}$, there was no significant difference in proliferation rate of tumor-associated HEECs and normal HEECs.

procedure but without the primary antibody) showed no staining of the vessels. Western blot analysis showed higher LAMB1, VIM, MMP9, ABCC3, and CDC25B protein in tumor-associated HEECs (Fig. 5).

Proliferation of HEECs. As shown in Fig. 6, after cells were cultured for 24, 48, 72 and $96 \mathrm{~h}$, there was no significant difference in the proliferation rate of tumor-associated HEECs and normal HEECs $(\mathrm{P} \geq 0.05)$. The results revealed that endothelial cells isolated from endometrial cancer do not proliferate faster than HEECs isolated from normal endothelium in vitro.

Wound healing assay of the endothelial monolayer. The wound healing assay is a widely-used procedure that allows an examination of cell migration in response to an artificial wound produced on a cell monolayer. Fig. 7 shows a significantly enhanced migration in tumor-associated HEECs compared with normal HEECs under the same conditions, with the percentage of repaired area of $16.37 \pm 2.88 \mathrm{vs}$. $37.54 \pm 5.63(\mathrm{P} \leq 0.01)$. These results indicate that tumorassociated HEECs presented an augmented effect on wound healing ability.

Cell invasion assay of HEECs. The invasion of endothelial cells is also one of the critical features in the formation of new blood vessels. To determine the endothelial cell invasion, we investigated the invasion ability of HECCs through Transwell inserts. Significantly more cells were detected in the lower chamber in tumor-associated HEECs than in the control group ( $131 \pm 22$ vs. $189 \pm 31, \mathrm{P} \leq 0.05$, Fig. 8).

Tube formation assay of HEECs. The production of tubular structures is another important step in angiogenesis. HEECs plated on Matrigel aligned to form capillary-like structures 

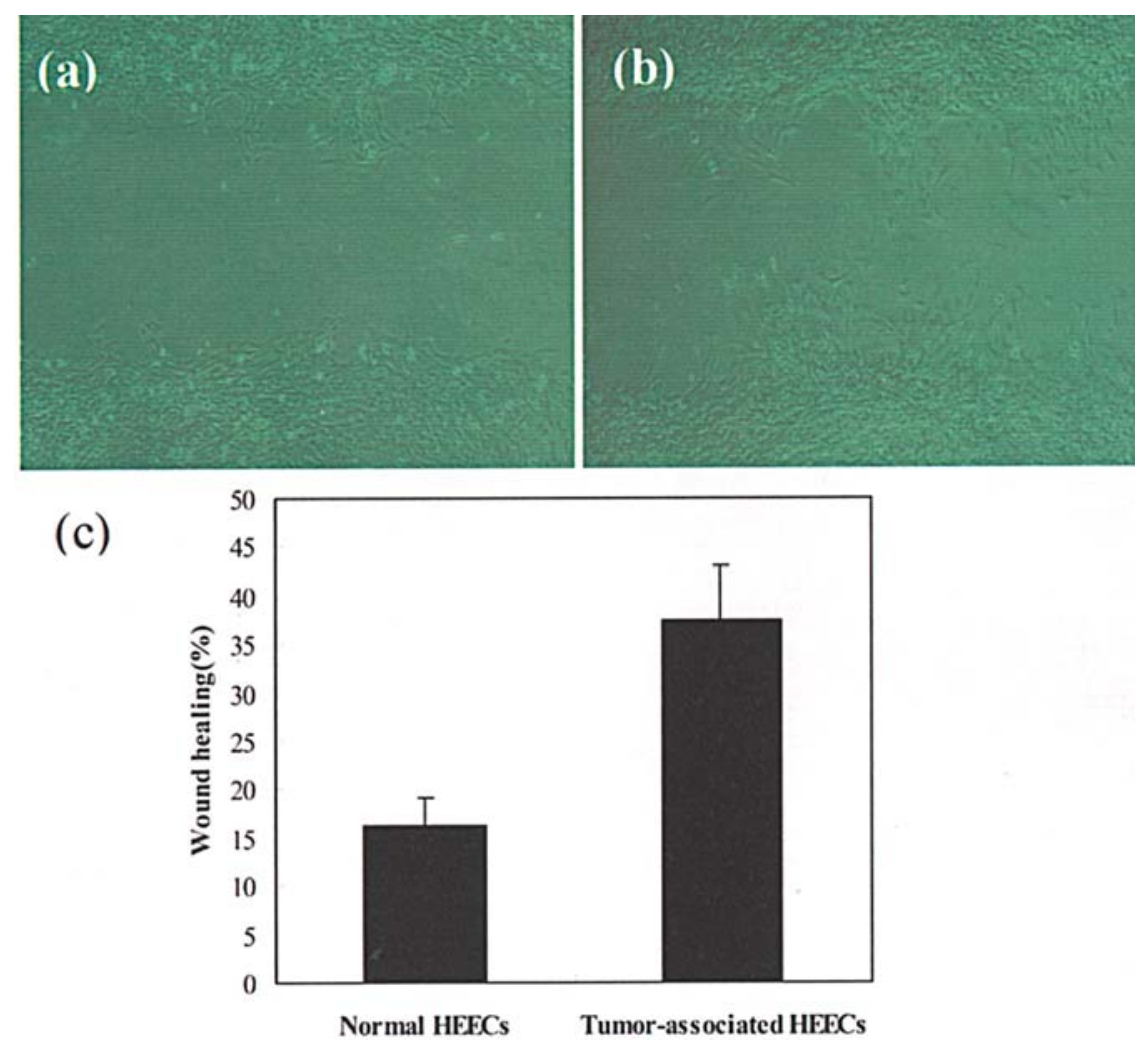

Figure 7. Wound healing assay of the endothelial monolayer. (a) Phase contrast photomicrographs of wounds in endothelial cell monolayers from normal endometrium; (b) wounds in endothelial cells from endometrial cancer. Original magnification, x100. (c) The percentage of repaired area of endothelial cells. ${ }^{* *} \mathrm{P} \leq 0.01$ vs. control.

with multicentric junctions (Fig. 9). More tube-like structures were observed in tumor-associated HEECs than normal HEECs $(56 \pm 18$ vs. $31 \pm 16, \mathrm{P} \leq 0.05)$. These data indicate that tumor-associated HEECs were functionally more powerful in angiogenesis than normal HEECs.

\section{Discussion}

It is well known that endothelial cells vary phenotypically depending on the organ of origin (14). There are limited data concerning genomic differences in tumor-associated endothelial cells from colon, breast, brain, and ovarian tumors (9-12). Previous global expression profile analysis has examined the normal endometria of normal cycling women and compared these data to different histological types of endometrial cancers (15). However, no data regarding tumorassociated endothelial cells from endometrial cancer have been evaluated using microarray analysis until now. To the best of our knowledge, this is the first study of genomic profiling of endometrial tumor-associated endothelial cells.

The endometrium is one of the most dynamic tissues in mammals due to the constantly changing levels of ovarian steroids which are believed to drastically affect gene expression. In order to minimize the change of gene expression caused by alteration in ovarian steroids, we chose to examine endothelial cells isolated from malignant and normal endometrial tissues matched for age and the period of menstrual cycle.
The major finding of the present study is that endometrial tumor-associated endothelial cells contain a large number of gene alterations in comparison with normal endometrial endothelial cells and, therefore, were likely to reflect differences in the ability of angiogenesis of endometrial cancer. Pathway analyses of these overexpressed genes showed that pathways of cell cycle, cell adhesion molecules (CAMs), focal adhesion, and extracellular matrix (ECM)receptor interaction were obviously predominant. Loss of tumor suppressor activities was also found in our gene array analysis and several genes with potential antiangiogenic or antiproliferative roles were also depressed.

Data from our study shows that SPP1 and LAMB1, genes related to ECM (extracellular matrix) -receptor interaction, were obviously elevated in tumor-related endothelium. SPP1 (The cytokine/extracellular matrix protein osteopontin, OPN) is an integrin-binding protein overexpressed in various experimental models of malignancy and appears to be involved in tumorigenesis and metastasis in several types of cancers (18-20). Hirama and colleagues reported that culture medium with murine neuroblastoma $\mathrm{C} 1300$ cells transfected with SPP1 gene significantly stimulates human umbilical vein endothelial cell migration and induces neovascularization in mice by dorsal air sac assay (21). Moreover, Leali and colleagues found SPP1 expression was elevated in the newly formed endothelium of the chick embryo chorioallantoic membrane (CAM) and of murine s.c. Matrigel plug implants (22). Recombinant SPP1, the fusion protein GST-SPP1, and 
Table V. Significant pathways involved in the specific phenotype of endothelial cells from endometrial cancer.

\begin{tabular}{|c|c|c|c|c|}
\hline Pathway Name & Gene & Fold change & P-value & Q-value \\
\hline \multirow[t]{6}{*}{ MAPK signaling pathway } & $\mathrm{CDC} 25 \mathrm{~B}$ & 8.788 & & \\
\hline & HSPA8 & 11.084 & 0.040498 & 0.0 \\
\hline & PRKCD & 5.5152 & & \\
\hline & $\mathrm{CDC} 25 \mathrm{~B}$ & 8.788 & & \\
\hline & CDKN2A & 0.3118 & & \\
\hline & YWHAB & 6.6523 & & \\
\hline \multirow[t]{5}{*}{ Cell cycle } & EGFL6 & 11.079 & 0.0 & 0.0 \\
\hline & PCNA & 2.1749 & & \\
\hline & COL3A1 & 0.2244 & & \\
\hline & CTNNB1 & 0.2144 & & \\
\hline & LAMB1 & 8.178 & & \\
\hline \multirow[t]{4}{*}{ Focal adhesion } & SPP1 & 17.087 & & 0.0 \\
\hline & BIRC3 & 2.1397 & 0.004141 & \\
\hline & COL3A1 & 0.2244 & & \\
\hline & LAMB 1 & 8.178 & & \\
\hline \multirow[t]{3}{*}{ ECM-receptor interaction } & SPP1 & 17.087 & & 0.0 \\
\hline & ITGB7 & 2.541 & 0.024879 & \\
\hline & CAPG & 5.177 & & \\
\hline \multirow{2}{*}{$\begin{array}{l}\text { Actin cytoskeleton organization } \\
\text { and biogenesis }\end{array}$} & CAPZA1 & 8.179 & 0.006825 & 0.0 \\
\hline & FOS & 0.3434 & & \\
\hline \multirow[t]{5}{*}{ Toll-like receptor signaling pathway } & CD14 & 0.3921 & 0.138972 & 0.0 \\
\hline & CLDN4 & 2.1914 & & \\
\hline & ITGB7 & 5.514 & & \\
\hline & ITGAM & 2.17174 & & \\
\hline & ICAM1 & 0.4957 & & \\
\hline Cell adhesion molecules (CAMs) & CLDN7 & 0.4279 & $5.0 \mathrm{E}-5$ & 0.0 \\
\hline \multirow[t]{2}{*}{ mTOR signaling pathway } & EIF4EBP1 & 0.2248 & 0.083687 & 0.0 \\
\hline & CTNNB1 & 0.2144 & & \\
\hline Wnt signaling pathway & CCND3 & 0.3991 & 0.238018 & 0.0 \\
\hline TGF-ß signaling pathway & ID4 & 8.7446 & 0.144675 & 0.0 \\
\hline
\end{tabular}

FC, fold change; The q-value of a gene in SAM results is a false discovery rate for the gene list that includes the gene and all genes that are more significant.

the deletion mutant GST-DeltaRGD-SPP1 were angiogenic in the CAM assay. These results strongly implied that SPP1 had played an important role in tumor growth through the enhancement of angiogenesis in vivo. Previous studies indicated that SPP1 induced endothelial cell migration and up-regulated endothelial cell migration induced by VEGF $(23,24)$. However, the effect of SPP1 on tumorigenesis as an angiogenic factor remains to be clarified. In the present work, we report the up-regulated expression of SPP1 in tumorassociated HEECs. The same conclusion had been drawn in the vasculature from ovarian cancers as well (12). Positive SPP1 expression with a consistent cytoplasmic localization in tumor-associated vasculature was observed in malignant human endometrium by immunohistochemistry or Western blotting. We therefore presume that SPP1 plays an important role in neovascularization of endometrial cancer, and further investigation should be conducted in the future.

The other up-regulated gene related to ECM -receptor interaction in the present study is LAMB1 (laminin, $\beta 1$ chain), which is a constituent of laminin-8. Laminins are major components of vascular and parenchymal basement membranes, which have been implicated in a wide variety of biological processes including cell adhesion, differentiation, migration, signaling and metastasis. LAMB1 is now known to be involved in cell adhesion, positive regulation of epithelial cell proliferation and cell migration. Experimental evidence described by Fujita and colleagues have identified three basement membrane laminins that share the same $\beta 1$ chain (LAMB1), namely laminin-2, laminin-8, and laminin-10, as new breast carcinoma angiogenic markers and may associate with breast tumor progression (25). A similar switch from ß2-containing to $\beta 1$-containing vascular laminins has also been shown to occur during the progression of brain gliomas and may constitute a general feature of vascular basement membrane changes in solid tumors (26). No data regarding the expression of this gene in endometrial cancer have been reported until now. The relationship between overexpressed LAMB1 in endothelial cells and angiogenesis in endometrial cancer is still unknown.

Matrix metalloproteinase (MMP)-mediated degradation of the extracellular matrix is a key point in tumor development and expansion. In the present study, we found elevated 


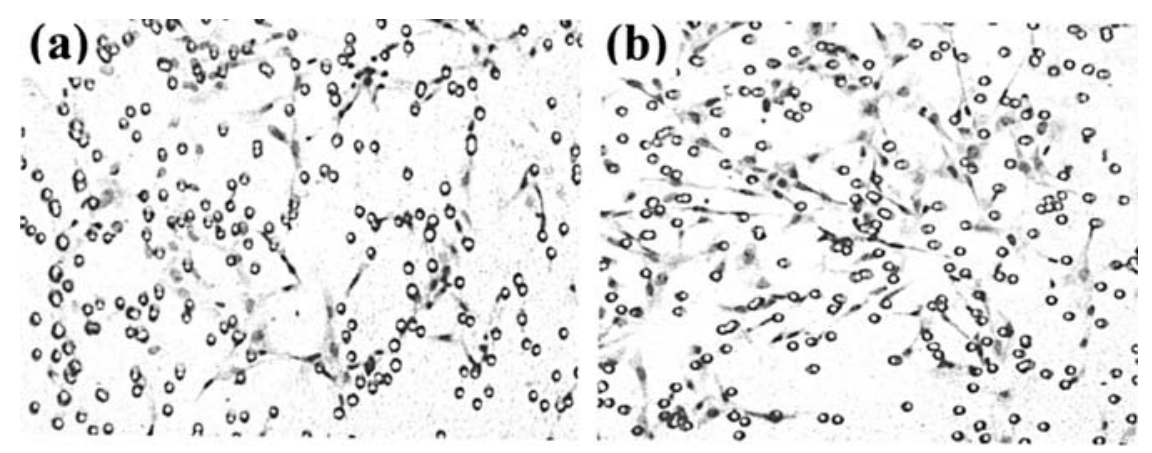

(c)

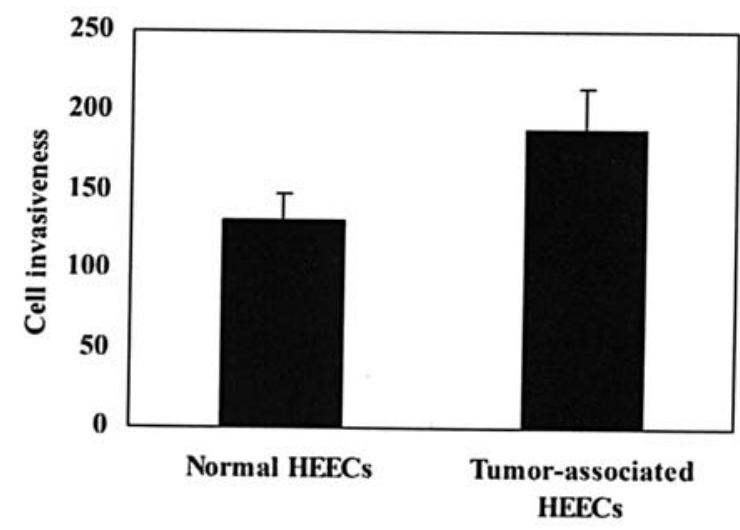

Figure 8. Relative invasion by endothelial cells from normal endometria and endometrial cancers. (a and b) Endothelial cells were on the lower surface of the transwell filters (magnification, x200). (a) Endothelial cells from normal endometrium; (b) endothelial cells from endometrial cancer. (c) The number of cells that invaded through the filters was counted under a microscope (magnification, x400) in five views. Columns, mean of three independent experiments; bars, SD. ${ }^{*} \mathrm{P} \leq 0.05$ vs. control.
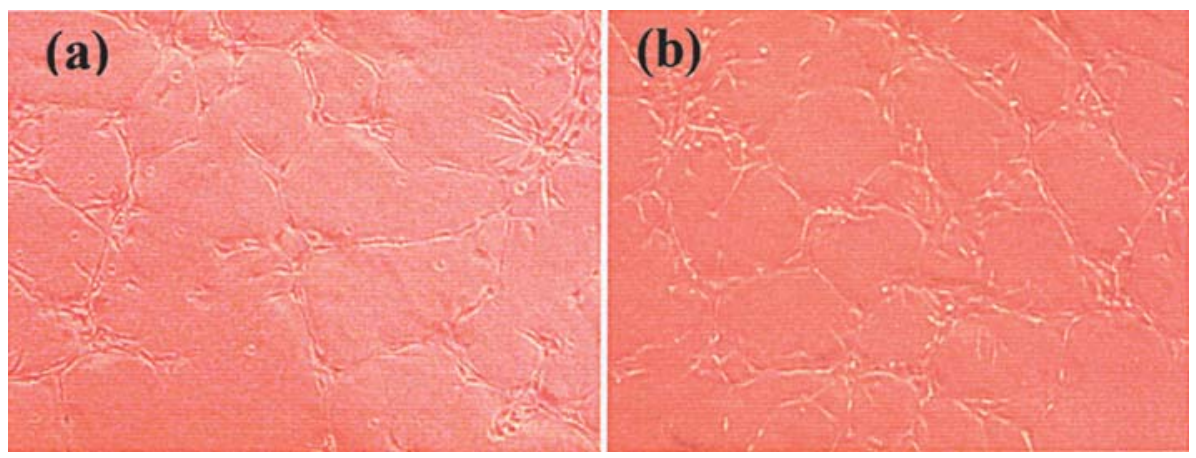

Figure 9. Tube formation of endothelial cells from normal endometrium and endometrial cancer. Cells cultured on Matrigel for $14 \mathrm{~h}$, then photographed under a microscope (magnification, x200) and branching points were counted. (a) Endothelial cells from normal endometrium; (b) endothelial cells from endometrial cancer.

expression of MMP9 and MMP10 in endometrial tumorrelated endothelium. MMP9 is one of the most important and well-characterized members of the MMP family and is considered to be closely associated with angiogenesis, which had been verified in breast and ovarian cancer $(9,12)$. Karahan and colleagues found MMP-9 was expressed in a high percentage of endometrial carcinomas and their expression may be associated closely with vascular and lymphatic invasion (27). Moreover, MMP10 (stromelysin-2), previously not known to be related to angiogenesis, is now presumed to degrade various components of the extracellular matrix in disease processes, such as arthritis and metastasis. Several studies found increased expression of MMP10 in prostate and gastric cancers compared to benign tissues
$(28,29)$. Van Themsche and colleagues provided evidence that overexpression of MMP10 promoted lymphoid tumor development (30). MMP10 was dramatically overexpressed in metastatic non-small cell lung cancer compared with nonmetastatic disease in a study examined by suppression subtractive hybridization and mircroarray (31). These results implied that there might be some relationship between MMP9 and MMP10 and the enhancement of angiogenesis in some malignant diseases. In our study, general immunohistochemial expression of MMP9 in stromal, epithelial and endothelial cells were detected in endometrial cancer. Increased expression of MMP9 and MMP10 in endometrial endothelia indicated that these two MMPs might be associated with promoted angiogenesis in malignant 
endometrium although their precise mechanism still awaits investigation.

Degradation of the extracellular matrix, endothelial cell migration and the production of tubular structures are important steps in angiogenesis. The results of the present investigation show that tumor-associated HEECs migrated faster in wound healing assay than normal HEECs. Likewise, tumor-associated HEECs migrated through a Matrigel-coated filter faster and yielded more tube-like structures. These data indicated that tumor-associated HEECs were more functionally powerful in angiogenesis although they did not proliferate faster than normal HEECs in vitro. Some simultaneously activated signaling pathways, such as MAPK and TGF- $\beta$ signaling pathway, may play an important role in angiogenesis. At the same time, some depressed signaling pathways, such as mTOR and Wnt signaling pathway, may also participate in this process. However, their roles in endometrial tumorassociated angiogenesis and the signals that regulate their expression remain unknown.

In summary, the gene expression profiles derived in the current study define unique alterations in vascular gene expression in endometrial carcinoma. Our findings may be useful not only as an aid in characterizing the function of tumor-specific HEEC genes in endometrial cancer, but also as a means to find potential targets to achieve further gains in therapeutic benefit. Additional work is needed to define the role of the novel genes identified here in processes of endometrial cancer angiogenesis.

\section{Acknowledgements}

This work was supported by the grants from The Shandong Provincial Natural Science Foundation (No. Y2006C88).

\section{References}

1. Burke C, Foley M, Lenehan P, Kelehan P and Flannelly G: Early stage endometrial carcinoma-a study of management and outcome. Ir Med J 100: 621-623, 2007.

2. Zusterzeel PL, Bekkers RL, Hendriks JC, Neesham DN, Rome RM and Quinn MA: Prognostic factors for recurrence in patients with FIGO stage I and II, intermediate or high risk endometrial cancer. Acta Obstet Gynecol Scand 87: 240-246, 2008.

3. Ayhan A, Taskiran C, Celik C, Yuce K and Kucukali T: The influence of cytoreductive surgery on survival and morbidity in stage IVB endometrial cancer. Int J Gynecol Cancer 12: 448-453, 2002.

4. Sivridis E: Angiogenesis and endometrial cancer. Anticancer Res 21: 4383-4388, 2001.

5. Ozbudak IH, Karaveli S, Simsek T, Erdogan G and Pestereli E: Neoangiogenesis and expression of hypoxia-inducible factor 1 alpha, vascular endothelial growth factor, and glucose transporter-1 in endometrioid type endometrium adenocarcinomas. Gynecol Oncol 108: 603-608, 2008.

6. Kamat AA, Merritt WM, Coffey D, et al: Clinical and biological significance of vascular endothelial growth factor in endometrial cancer. Clin Cancer Res 13: 7487-7495, 2007.

7. Morikawa S, Baluk P, Kaidoh T, et al: Abnormalities in pericytes on blood vessels and endothelial sprouts in tumors. Am J Pathol 160: 985-1000, 2002.

8. Baluk P, Morikawa S, Haskell A, Mancuso M and McDonald DM: Abnormalities of basement membrane on blood vessels and endothelial sprouts in tumors. Am J Pathol 163: 1801-1815, 2003.

9. Parker BS, Argani P, Cook BP, et al: Alterations in vascular gene expression in invasive breast carcinoma. Cancer Res 64: 7857-7866. Erratum in: Cancer Res 64: 8794, 2004.

10. St Croix B, Rago C, Velculescu V, et al: Genes expressed in human tumor endothelium. Science 289: 1197-1202, 2000.
11. Madden SL, Cook BP, Nacht M, et al: Vascular gene expression in nonneoplastic and malignant brain. Am J Pathol 165: 601608, 2004.

12. Lu C, Bonome T, Li Y, Kamat AA, et al: Gene alterations identified by expression profiling in tumor-associated endothelial cells from invasive ovarian carcinoma. Cancer Res 67: 1757-1768, 2007.

13. Sha G, Wu D, Zhang L, et al: Differentially expressed genes in human endometrial endothelial cells derived from eutopic endometrium of patients with endometriosis compared with those from patients without endometriosis. Human Reprod 22: 3159-3169, 2007

14. Langley RR, Ramirez KM, Tsan RZ, Van Arsdall M, Nilsson MB and Fidler IJ: Tissue-specific microvascular endothelial cell lines from $\mathrm{H}-2 \mathrm{~K}(\mathrm{~b})$-tsA58 mice for studies of angiogenesis and metastasis. Cancer Res 63: 2971-2976, 2003.

15. Maxwell GL, Chandramouli GV, Dainty L, Litzi TJ, Berchuck A, Barrett JC and Risinger JI: Microarray analysis of endometrial carcinomas and mixed mullerian tumors reveals distinct gene expression profiles associated with different histologic types of uterine cancer. Clin Cancer Res 11: 4056-4066, 2005.

16. Livak KJ and Schmittgen TD: Analysis of relative gene expression data using real-time quantitative PCR and the $2\left(^{-\Delta \Delta C(T)}\right)$ method. Methods 25: 402-408, 2001.

17. Mao X, Cai T, Olyarchuk JG and Wei L: Automated genome annotation and pathway identification using the KEGG Orthology (KO) as a controlled vocabulary. Bioinformatics 21 : 3787-3793, 2005

18. Agrawal D, Chen T, Irby R, et al: Osteopontin identified as lead marker of colon cancer progression, using pooled sample expression profiling. J Natl Cancer Inst 94: 513-521, 2002.

19. Briese J, Schulte HM, Bamberger CM, Löning T and Bamberger AM: Expression pattern of osteopontin in endometrial carcinoma: correlation with expression of the adhesion molecule CEACAM1. Int J Gynecol Pathol 25: 161-169, 2006.

20. Coppola D, Szabo M, Boulware D, Muraca P, Alsarraj M, Chambers AF and Yeatman TJ: Correlation of osteopontin protein expression and pathological stage across a wide variety of tumor histologies. Clin Cancer Res 10: 184-190, 2004.

21. Hirama M, Takahashi F, Takahashi K, et al: Osteopontin overproduced by tumor cells acts as a potent angiogenic factor contributing to tumor growth. Cancer Lett 198: 107-117, 2003.

22. Leali D, Dell'Era P, Stabile H, et al: Osteopontin (Eta-1) and fibroblast growth factor- 2 cross-talk in angiogenesis. J Immunol 171: 1085-1093, 2003.

23. Shijubo N, Uede T, Kon S, Nagata M and Abe S: Vascular endothelial growth factor and osteopontin in tumor biology. Crit Rev Oncog 11: 135-146, 2000.

24. Takano S, Tsuboi K, Tomono Y, Mitsui Y and Nose T: Tissue factor, osteopontin, alphavbeta3 integrin expression in microvasculature of gliomas associated with vascular endothelial growth factor expression. Br J Cancer 82: 1967-1973, 2000.

25. Fujita M, Khazenzon NM, Bose S, et al: Overexpression of beta1-chain-containing laminins in capillary basement membranes of human breast cancer and its metastases. Breast Cancer Res 7: 166-167, 2005.

26. Ljubimova JY, Fujita M, Khazenzon NM, Ljubimov AV and Black KL: Changes in laminin isoforms associated with brain tumor invasion and angiogenesis. Front Biosci 11: 81-88, 2006.

27. Karahan N, Güney M, Baspinar S, Oral B, Kapucuoglu N and Mungan T: Expression of gelatinase (MMP-2 and MMP-9) and cyclooxygenase-2 (COX-2) in endometrial carcinoma. Eur J Gynaecol Oncol 28: 184-188, 2007.

28. Riddick AC, Shukla CJ, Pennington CJ, et al: Identification of degradome components associated with prostate cancer progression by expression analysis of human prostatic tissues. Br J Cancer 92: 2171-2180, 2005.

29. Aung PP, Oue N, Mitani Y, et al: Systematic search for gastric cancer-specific genes based on SAGE data: melanoma inhibitory activity and matrix metalloproteinase-10 are novel prognostic factors in patients with gastric cancer. Oncogene 25: 2546-2557, 2006.

30. Van Themsche C, Alain T, Kossakowska AE, Urbanski S, Potworowski EF and St-Pierre Y: Stromelysin-2 (matrix metalloproteinase 10) is inducible in lymphoma cells and accelerates the growth of lymphoid tumors in vivo. J Immunol 173: 3605-3611, 2004.

31. Lin TS, Chiou SH, Wang LS, et al: Expression spectra of matrix metalloproteinases in metastatic non-small cell lung cancer. Oncol Rep 12: 717-723, 2004. 